\title{
Paternalist Liderliğin Örgütsel Adalet Algısı Üzerine Etkisi: Sağlık Çalışanları Üzerinde Bir Araştırma
}

\section{The Effect of Paternalist Leadership on Organizational Justice Perception: A Research on Healthcare Employees}

\author{
Dr. Öğr. Üyesi Mustafa NAL (D) 1 , Prof. Dr. Mehveş TARIM (D)2
}

\begin{abstract}
$\ddot{O} \mathbf{z}$
$\mathrm{Bu}$ araştırma, sağlık yöneticilerin paternalist liderlik davranışlarının, çalışanların örgütsel adalet algısı üzerindeki etkisini incelemek amacı ile yapılmıştır. Bu araştırmada, sağlık çalışanlarının sosyodemografik özelliklerini tespit etmek için Kişisel Bilgi Formu, paternalist liderlik algısını ölçmek için Pellegrini ve Scandura (2006) tarafından geliştirilen Paternalist Liderlik Ölçeği ve örgütsel adalet algısını ölçmek için Niehoff ve Moorman (1993) tarafından geliştirilen Örgütsel Adalet Ölçeği kullanılmıştır. Bu araştırmada Kastamonu, Çankırı ve Karabük illerinde bulunan kamu ve özel sektörde faaliyet gösteren dört hastane örneklem olarak seçilmiştir. Araştırma 2016-2017 yılları arasında 683 kişi üzerinde yapılmıştır. Paternalist liderliğin, örgütsel adalet algısı üzerine yüksek düzeyde ve pozitif yönlü anlamlı bir etkisi olduğu belirlenmiştir ( $\mathrm{r}=659, \mathrm{t}=22,865, \mathrm{p}<0,01)$. Paternalist liderlik davranışı arttıkça, örgütsel adalet algısının da arttığı saptanmıştır. Tüm bu sonuçlara göre paternalist liderliğin, sağlık çalışanları üzerinde etkin bir liderlik modeli olduğu söylenebilir.
\end{abstract}

Anahtar Kelimeler: Paternalist liderlik, örgütsel adalet, sağlık personeli, liderlik

Makale Türü: Araştırma

\begin{abstract}
This study analyzes the relationship between health administrators' paternalistic leadership behaviors and, employee of organizational justice. Perceptions of paternalistic leadership was measured by using the Paternalistic Leadership Scale developed by Pellegrini and Scandura (2006). Perceptions of organizational justice were measured by using the Organizational Justice Scale developed by Niehoff and Moorman (1993). The study sample consisted of four public and private hospitals in Kastamonu, Çankırı and Karabük. The study was conducted on 683 participants between the years of 2016 and 2017. Paternalistic leadership was found to have a significantly high positive effect on perceptions of organizational justice $(r=659$, $\mathrm{t}=22,865, \mathrm{p}<0,01)$. Increased paternalistic leadership behavior led to increased perceptions of organizational justice. It is concluded from this study that paternalistic leadership is an effective leadership model for healthcare employee.
\end{abstract}

Keywords: Paternalist leadership, organizational justice, healthcare employee, leadership

Paper Type: Research

\footnotetext{
${ }^{1}$ Afyon Kocatepe Üniversitesi, Dinar Uygulamalı Bilimler Yüksekokulu, mustafanal@aku.edu.tr.

${ }^{2}$ Marmara Üniversitesi, Sağlık Bilimleri Fakültesi, mtarim@marmara.edu.tr.

Atıf için (to cite): Nal, M ve Tarım, M. (2019). Paternalist Liderliğin Örgütsel Adalet Algısı Üzerine Etkisi: Sağlık Çalışanları Üzerinde Bir Araştırma. Afyon Kocatepe Üniversitesi Sosyal Bilimler Dergisi, 21(4), 1193-1204.
} 


\section{Giriş}

Sağl1k hizmetlerinin özelliklerinden biri de hizmetin sunumunda emeğin yoğun olmasıdır, bu nedenle sağlık sektöründe insan kaynakları önemli bir yere sahiptir. Sağlık organizasyonlarının, etkili ve verimli bir şekilde amaçlarına ulaşabilmesi için, yaptığı işi seven, motivasyonu yerinde insan kaynaklarına ihtiyacı vardır.

Kendisini örgütsel amaçlara adamış bir lider, yönetim fonksiyonlarını yerine getirirken ilk olarak çalışanların örgütsel amaçlar doğrultusunda hareket etmesini sağlamak için onları en iyi şekilde motive etmesi gerekmektedir (Önen \& Kanayran, 2015). Bu nedenle liderin, organizasyon içinde çalışanların motivasyonunu sağlama konusunda önemli bir rolü ve fonksiyonu vardır (Önen \& Kanayran, 2015). Lider olabilmek için tüm takipçilerine en iyi şekilde rehberlik etme ve onları etkileme yeteneğine sahip olmak gerekir. Liderin takipçilerini etkilemesi ve onlara rehberlik edebilmesi için kendi deneyimleri ve yaşam koşullarına bağlı bir liderlik tarzı benimsemesi gerekmektedir (Anwar, 2013).

Yapılan bir çalışmada, Türkiye'nin paternalizm ve topluluğa bağl1lık boyutları yönünden on ülke arasından ikinci sırada olduğu tespit edilmiştir (Aycan vd., 2000). Ayrıca yapılan bazı çalışmalarda da (Pellegrini ve Scandura, 2006; Yaman, 2011; Türesin, 2012) Türkiye'de Paternalist Liderliğin yüksek düzeyde olduğunu göstermektedir.

Örgüt içinde lider davranışlarının, çalışanların örgütsel algı ve davranışları üzerine etkisi olduğu bilinmektedir. İnsanlar bulundukları organizasyon içinde, yöneticileri, iş arkadaşları ve işleri ile ilgili gözlemler yapar. Çalışanların bu gözlemleri sonucunda, işi, organizasyonu, yöneticileri ve çalışma arkadaşları ile ilgili bir takım algılar oluşur ve bu algılar çalışanların davranışlarını ve başarılarını etkiler. Çalışanların gösterdiği davranışları önemli derecede etkileyen bu algılardan biri de örgütsel adalet algısıdır (Acar, 2013).

Örgütsel adalet, bir kurum için önemli bir nitelik olduğundan dolayı bir organizasyonun başarısı ya da başarısızlı̆̆ını etkileyen önemli faktörlerden biridir (Tahseen \& Akhtar, 2016). Örgütsel adalet, çalışanların uyumlu çalışmalarını sağlamakta iken, örgütsel adaletsizlik ise çalışanlar arasındaki uyumu bozmakta ve sonuç olarak bireysel ve örgütsel zararlara neden olabilmektedir (Cropanzano, Bowen, \& Gilliland, 2007).

Örgütsel adalet kavramı ile ilgili tanımlar incelendiğinde örgüt içinde örgütsel adaletin sağlanmasının önemli bir husus olduğu söylenebilir. Başka bir ifade ile çalışanlar tarafından adaletli bir örgüt ortamı olduğu düşünülüyorsa, örgütsel amaç ve hedeflere ulaşma konusunda çalışanlar üzerinde olumlu yönde etkisi olması beklenmekte iken, bunun aksi bir durumda örgütsel açıdan olumsuz sonuçlar doğurması beklenmektedir. Genel olarak, örgütsel amaç ve hedefleri gerçekleştirme aşamalarında en önemli kaynaklardan biri olan insan kaynaklarının (çalışanların), iş doyumu, örgütsel vatandaşlık, verimlilik, örgütsel güven gibi örgüte katma değer katacak unsurlar üzerine örgütsel adaletin önemli bir etkisi vardır. $\mathrm{Bu}$ nedenle çalışanların örgütsel amaç ve hedefleri gerçekleştirme sürecinde etkin ve verimli bir şekilde çalışmalarını beklemek için adaletli bir iş ortamının oluşturulması kaçınılmaz bir gerekliliktir (Tanrıverdi \& Paşaoğlu, 2014).

Paternalist liderliğin, kolektivist kültürlere sahip toplumlarda çalışanların tutumlarına pozitif bir etkisi bulunmaktadır (Gelfand vd., 2007). Bu nedenlerden dolayı, Türkiye'de sağlık yöneticilerinin göstermiş olduğu paternalistik liderlik davranışının, çalışanların örgütsel adalet algıları üzerine olumlu etkisi olabileceği düşünülmektedir. Yapılan araştırmalara incelendiğinde, Paternalist liderliğin, Türkiye'nin kültürel yapısı ile uyumlu olduğu söylenebilir.

$\mathrm{Bu}$ araştırmanın amacı çalışanlarını Paternalist Liderlik davranışlarının, çalışanların örgütsel adalet algısı üzerinde etkisi olup olmadığını ortaya koyarak, sağlık yöneticilerine yol gösterici olmak ve literatüre katkı sağlamaktır. 


\section{Paternalist Liderlik}

Liderlik, örgütün geleceğe yönelik vizyonunu belirleyip, çevresindekilere bunu anlatmak ve belirlenen vizyonu ve misyonu hayata geçirebilmek için insanları bu yönde davranışa geçirebilmektir (Sur, 2013). Liderlik konusunda yapılan tanımlar incelendiğinde ve bir sentez yapıldığında genel tanım olarak "liderlik, bir grup insanı belirlenen amaçlar etrafinda bir araya getirmek, bu amaçları gerçekleştirmek için onları harekete geçirmek ve bunları gerçekleştirmek için gerekli olan bilgi ve yeteneklerin toplamıdır" denilebilir (Eren, 2015).

Paternalist liderlik, hiyerarşik ilişkiler içinde liderin bir nevi aile bireyleri gibi astlarının kişisel ve profesyonel hayatlarına rehberlik eden ve karşılığında ise astların kendisine karşı sadık olmalarını bekleyen bir yaklaşım olarak tanımlamaktadır (Gelfand vd., 2007). Paternalist lider, astların özel yaşamlarının içerisine bile dahil olur, astlarına bir "baba" gibi yaklaşmakta ve onları koruyup kollamaktadır (Pellegrini \& Scandura, 2006).

Paternalizm, birçok ülkede tercih edilen bir liderlik modelidir, kollektivizm ve yüksek güç mesafesine sahip birçok ülkede örneğin Türkiye, Hindistan, Çin ve Meksika'da liderlik modeli olarak tercih edilmektedir (Salminen-Karlsson, 2015). Kültürel bir özellik gösteren Paternalist Liderlik, daha çok Pasifik Asya, Orta Doğu ve Latin Amerika toplumlarında görülmektedir. Fakat son zamanlarda Paternalist Liderlik doğu ve batı toplumlarında iş ve sosyal hayata dair bir grup problemlerle başa çıkabilmek için bir çare olarak bakılmaktadır (Aycan, 2006). Paternalist özelliğe sahip kültürlerde, ebeveynler ve yaşlı aile üyeleri, genç üyelerinin refahını korumak, onların kararları üzerinde rol almak, onların faaliyetlerini disipline etmek ve onlar adına hareket etmek gibi rolleri vardır (Mustafa \& Lines, 2012).

Araştırmacılar, paternalist liderliği kültürel bağlamda olumlu ve olumsuz olarak farklı şekilde yorumlamaktadır. Örneğin batılı araştırmacılar paternalist liderliği olumsuz olarak değerlendirmekte iken, paternalist liderliğin yaygın görüldüğü toplumlardaki araştırmacılar ise paternalist liderliği olumlu olarak değerlendirmektedir (Salminen-Karlsson, 2015). Paternalist liderin, çalışanın aile hayatı ile ilgilenmesi, çalışanlar tarafından bireyci kültürlerde gizlilik ihlali olarak algilanabilirken, toplulukçu kültürlerde istenen ve beklenen bir olay olarak karşılanabilmektedir (Aycan, 2006).

Paternalist liderlik yaklaşımının üç ayrı öğesi vardır: otoriter liderlik, iyilik sever liderlik ve ahlaki liderliktir (Cheng vd., 2014: 83). Otoriter liderlik, mutlak otorite ve kontrol ile astlar1 üzerinde sıkı bir yönetim uygulayan ve itaat bekleyen bir liderin davranışları ifade eder. Otoriterlik liderlik, astların liderin emirlerine sorgusuz sualsiz uyduğu, liderin astların üzerinde oluşturduğu yetki ve egemenlik olarak tanımlanabilir (Lu \& Hsu, 2015).

İyiliksever Liderlik, astları ile iyi ilişkiler kurma anlamına gelir (Anwar, 2013). İyiliksever lider, aile bireylerinin ve astlarının refahı için kişisel bir kaygı gösteren karakterdeki lideri ifade eder (Lu \& Hsu, 2015). İyiliksever liderlik, astlarının kişisel ve ailesel bir bütünlük içinde huzurlu olmaları için kaygı güden lideri ifade eder (Cheng \& Wang, 2015). Lider çalışanları ile özenle ilgilenir ve dostça bir çalışma ortamı oluşturur. Çalışma ortamından memnun olan çalışanların memnuniyetlerini verimlilik olarak göstermeleri beklenmektedir (Anwar, 2013).

Ahlaki liderlik, ölçülü olmayı ifade eder. Ayrıca üstün kişisel erdemli liderlik davranışı olarak ahlaki liderlik, fedakarca hareket eden, (örneğin, ahlaki karakter ve bütünlük), öz-disipline sahip, örnek liderliği ifade eder. (Cheng \& Wang, 2015). Ahlaki liderlik, çoğunlukla bencilce hareket etmeyen, dürüst, üstün ahlaki karakterli ve örnek davranışlar selgilerler (Cheng \& Wang, 2014). Lider takipçileri için alacağı kararlarda adil ve etik ilkeler doğrultusunda kararlar verir. $\mathrm{Bu}$ sayede etik ve mutlu bir çalışma ortamı sağlanmış olur (Anwar, 2013). 


\section{2. Örgütsel Adalet}

Örgütsel adalet kavramı ilk olarak 1987'de Greenberg tarafindan “organizasyon içerisinde algılanan adalet" anlamında kullanılmıştır (Colquitt, Conlon, Wesson, Porter, \& Ng 2001). O zamandan beri, organizasyon içindeki "adalet" algısının bireylerin iş ilişkilerini nasıl şekillendirdiği, tutum, davranışlar, verimlilik ve motivasyon üzerine etkileri konusunda birçok araştırma yapılmıştır (MacLeod, 2015). Örgütsel adalet, çalışanların birlikte uyumlu çalışmasına olanak sağlarken, örgütsel adaletsizlik ise bireyler arasındaki uyumu bozmakta ve sonuç olarak bireysel ve örgütsel zararlara neden olabilmektedir (Cropanzano vd., 2007). Örgütsel adalet, bir kurum için önemli bir nitelik olduğundan dolayı bir organizasyonun başarısı ya da başarısızlığını etkileyen önemli faktörlerden biridir (Tahseen \& Akhtar, 2016).

Literatürde örgütsel adaletin yaygın olarak üç boyutta incelendiği görülmektedir. Örgütsel Adaletin boyutları; Dağıtım Adaleti, Prosedürel Adalet ve Etkileşim Adaleti, alt başlıklar altında açıklanmıştır.

\subsection{Dağıtım Adaleti}

Örgütsel adalet ile ilgili 1975 yılından önce yapılan çalışmaların büyük bir kısmının, dağıtım adaleti ile ilgili olduğu görülmektedir. Yapılan bu çalışmaların birçoğu ilk kez örgütsel adaleti değerlendirmek için referans olarak Adams'ın (1965) Eşitlik Teorisi’ni göstermektedir (Colquitt vd., 2001).

Dağıtımsal adalet, işçilerin ücret, terfi gibi ulaşabilecekleri sonuçların dağıtımıyla ilişkili yönetimsel kararlarla ilgili oluşacak adalet algısını ifade etmektedir (Malik \& Naeem, 2011). Dağıtımsal adalet, örgütlerde çalışanların elde ettiği ödül ve cezalar ile ilgili algıladıkları adaletin seviyesi olarak ifade edilmektedir (DeConinck, 2010). Çalışanlar, diğer çalışanların çabalarını (giriş faktörleri) ve elde ettikleri sonuçlar karşılaştırarak dağıtım adaleti belirlemek eğilimindedir. Kişinin elde ettiği sonuçlar; ücret, promosyonlar, tanınma gibi faktörler iken, örgüte giriş sırasındaki deneyim, nitelik ve çaba ise giriş faktörlerini oluşturmaktadır. Kişinin elde ettiği Sonuç ile Giriş faktörlerinin oranları eşdeğer olmadığında, adalet algısı eşitsizlik ile sonuçlanmaktadır (Nakra, 2014).

Dağıtım adaleti üzerine yapılan çalışmalar incelendiğinde organizasyon içinde dağıtım, belirlenen kurallara uygun olarak yapıldığı ölçüde, örgüt üyeleri tarafindan adil olarak algılandığını göstermektedir (Fortin, 2008).

\section{2. İslemsel Adalet}

Örgütsel adaletin boyutlarından biri olan İşlemsel Adalet, bazı durumlarda kazanımları belirleyen süreçlerin, elde edilen kazanımların kendisinden daha önemli olabileceği varsayımına dayanmaktadır (Cüce, Güney, \& Tayfur, 2013). Bireyler, dağıtımsal işlemlerin adilliğini değerlendirmek için dağıtım için kullanılan kurallardan faydalanır (Leventhal, 1980).

İşlemsel adalet süreci, ödül ve kaynakların tahsisini yapmak için kullanılan prosedürler ile ilgili algılanan adalet ile ilgili bir durumdur (Sia \& Tan, 2016). Ayrıca işlemsel adalet kariyer planlaması ve yönetimi, performans değerlendirme gibi konulardaki kararlarda hakkaniyet ilkesine uygun hareket edildiği ile ilgilidir ve bu nedenden dolayı örgüt üyelerini yakından ilgilendiren bir konudur (Eren, 2015). Leventhal, örgüt içinde süreç adaletinin sağlanabilmesi için altı kuralın yerine getirilmesi gerektiğini savunmaktadır. Bu kurallar şunlardır (Leventhal, 1980):

I. Tutarlılık kuralı: Dağıtıma yönelik prosedürlerin kişiler ve zaman ile tutarlı olması gerekir. Kaynakların dağıtım süreci ile ilgili olarak potansiyel alıcıların hepsine benzer prosedürleri uygulamak ve hiç kimseye özel avantaj sağlamamak gerekir. Bir başka ifade ile kişilere fırsat eşitliği sunulmalıdır.

II. Önyargılı olmama kuralı: Bir kişinin sürece dayalı adalet yargısı, kişisel öz çıkarların ve dar önyargılara körü körüne bağlılığın dağıtım sürecindeki tüm aşamalarda engellenmesini 
öngören bir önyargı bastırma kuralına dayanmalıdır. Kısacası süreçler inanç ve önyargılardan etkilenmemelidir.

III. Doğruluk kuralı: Bir kişinin prosedüre dayalı adalet ilkesi, dağıtım sürecini olabildiğince iyi bilgi ve bilgilendirilmiş görüş üzerine dayandırmanın gerekliliğini belirleyen bir doğruluk kuralına dayandırılmalıdır. Süreçler geçerli bilgiye dayanmalıdır. Elde edilen bilgi en az hata ile toplanmalı ve işlenmelidir.

IV. Düzeltebilirlik kurall: Düzeltilebilirlik kuralı, dağıtım sürecinde çeşitli durumlarda verilen kararları değiştirmek veya tersine çevirmek için gerekli firsatların var olması gerekir. Genel olarak, algılanan adalet düzeyi, dağıtım sürecinin çeşitli aşamalarında kararların incelenmesine ve değiştirilmesine izin veren itiraz prosedürlerinin (hem resmi hem gayri resmi olarak) varlığ ile artırılabilir.

V. Temsiliyet kuralı: Bir kişinin prosedür uygunluğuna ilişkin yargıları bir temsil niteliği kuralına dayanabilir. Dağıtım sürecinin tüm aşamalarının, dağıtım süreçlerinden etkilenen bireylerin temel endişelerini, değerlerini ve görünümünü yansıtan temsilciler seçilmeli ve onların kararlara katılımı sağlanmalıdır.

VI. Etik kural: Bir kişinin sürece dayalı adalete ilişkin kararları, dağıtım usullerinin o kişinin kabul ettiği temel ahlaki ve etik değerlerle uyumlu olması gerektiğini belirten bir etik kuralına dayanmalıdır. Dağıtım prosedürleri, kişisel etik ve ahlak standartlarını ihlal ettiğinde, algilanan adalet azaltılacaktır.

\subsection{Etkileșim Adaleti}

Etkileşimsel adalet, karar verme sürecinin uygulama ve iletişim boyutu ile ilgili konuları içermektedir (Coulguitt, 2001). Etkileşimsel adalet karar verme aşaması süresince bireylere neyin ve nasıl söylendiği ile ilgilidir. Çalışanlar birçok zaman örgüt içinde verilen kararların ve yöneticilerin kendilerine nasıl davrandıkları ile ilgilenirler (Bağc1, 2013). Etkileşimsel adalet, organizasyon içinde çalışanlara kişilerarası ilişkilerde nasıl davranıldığ veya bu ilişkilerin seviyesi ile ilgili çalışanların algıları ile ilgilidir. Etkileşimsel adalet ile İşlemsel Adalet arasındaki temel fark, algılanan adalet veya adaletsizliğin odaklandığı noktadır. İşlemsel adalet algıları, örgütün kendisine odaklanmakta iken, etkileşimsel adalet algıları, doğrudan çalışanın üstlerine odaklanmaktadır (Deconinck, 2010).

Grenberg (1993) etkileşimsel adaletin, Kişilerarası Adalet ve Bilgisel Adalet olarak iki boyuttan oluştuğunu savunmuştur (AlQurashi, 2015).

\subsubsection{Kişilerarası Adalet}

Örgütsel adalet, işyeri içindeki kişilerarası ilişkilerin önemli bir parçasıdır. Çalışanlar, organizasyonlarındaki süreçlerin, sonuçların ve kişiler arası muamelenin adilliğini gözlemlemektedirler (Miles, 2012). Kişilerarası ilişki adaleti, iş yerinde bireylere nasıl davranıldığ ile ilgili olmak ile birlikte bu davranışlar üzerinde durulan asıl nokta saygı ve adalettir (MacLeod, 2015). Etkileşimsel adalette yüz yüze iletişim önemli olduğu için, çalışanlar kendileri ile yakın ilişkiler kuran amirlerinin olmasını isterler (Nakra, 2014). Kişilerarası adalet, kazanımların belirlenmesinde ve işlemlerin yürütülmesinde yöneticilerin çalışanlarına ne kadar nezaket, kıymet ve sayg1 gösterdiğini ifade etmektedir (Colquitt vd., 2001).

\subsubsection{Bilgisel Adalet}

Bilgisel adalet, organizasyon içinde çalşanları ilgilendiren konularda bilgi ve açıklamaların şeffaf ve bütünlük içinde çalışanlar ile paylaşılması konusundaki algıya odaklanmaktadır (MacLeod, 2015). Çalışanlar kendileri ile ilgili kariyer ve iş konularındaki bilgilerin ne oranda yeterli ve gerçekçi bir biçimde paylaşıldığı ile ilgilenirler. Bilgi paylaşımı ne derece şeffaf, yeterli ve makul yapıldığı bilgisel adaletin konusu kapsamındadır. Çalışanlar üzerinde yapılan performans değerlendirilmesi sonuçlarının çalışanlar ile paylaşılması bilgisel 
adalete örnek verilebilir (Ünler, 2015). Bilgisel adalet, yöneticilerin çalışanlara sağladığı bilgi ve iletişimin, çalışanlar tarafından ne derece adil algılandığı ile ilgilidir. Organizasyon içinde bilgisel adaletin sağlanabilmesi için yöneticinin astlarına karar verme sürecini, karar verme yöntemini ve verilen kararların sonuçlarını kapsamlı ve net bir biçimde anlatması gerekmektedir. Bilgisel adalet algısını oluşturmak için açıklamaların dürüst ve içten olması gerekmektedir (Acar, 2013). Bilgisel adalet ayrıca örgüt içinde astların sosyal hak ve çıarlarının, özlük haklarının korunması ve buna üstlerinin sayg1 göstermesini gerektirmektedir (Eren, 2015).

\section{Yöntem}

\subsection{Araştırmanın Amacı ve Modeli}

$\mathrm{Bu}$ araştırma, Paternalist Liderliğin, Örgütsel Adalet Algisı üzerinde etkisi olup olmadığını ortaya koyarak, sağlık yöneticilerine yol gösterici olmak ve literatüre katkı sağlamak amacı ile yapılmıştır. Araştırmanın türü, ilişkisel tarama modelinde betimsel bir çalışmadır.

Araştırma için Marmara Üniversitesi Sağlık Bilimleri Enstitüsü Girişimsel Olmayan Klinik Araştırmalar Etik Kurulu onayı alınmıştır. Ayrıca araştırmanın yapılması planlanan kurumlardan ölçek uygulaması için yazılı izinler alınmıştır.

$\mathrm{Bu}$ araştırma, Çankırı Özel Karatekin Hastanesi, Kastamonu Özel Anadolu Hastanesi, Çankırı Devlet Hastanesi, Karabük İlinde bulunan adının açıklanması istenilmeyen bir kamu hastanesinde, Temmuz 2016 - Mart 2017 tarihleri arasında yapılmıştır. Araştırmanın modeli Şekil 1' de gösterilmiştir.

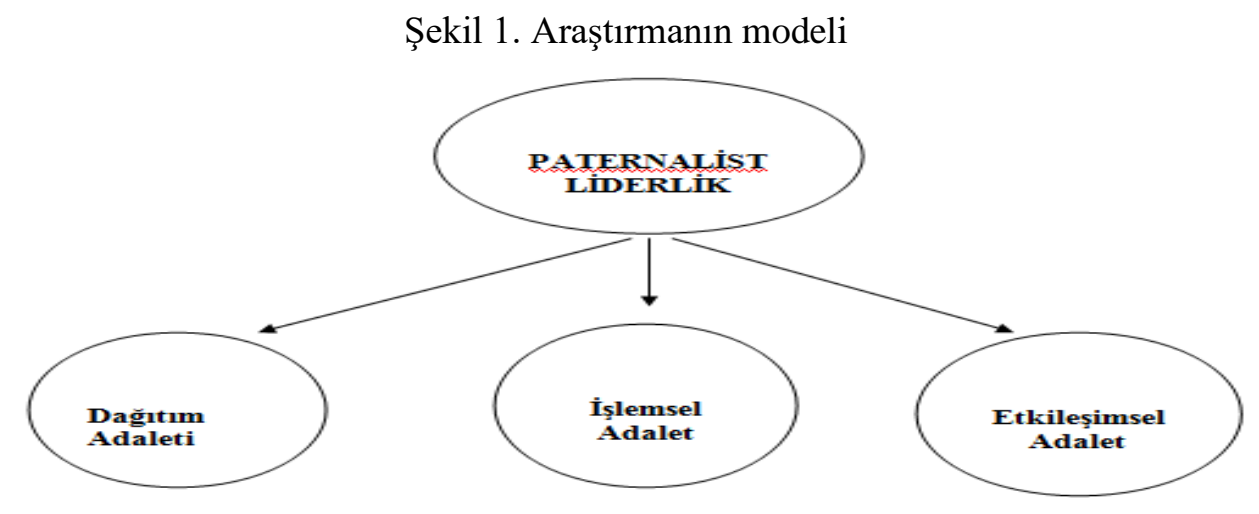

\subsection{Araştırmanın Hipotezleri}

$\mathrm{H}_{1}$ : Paternalist liderlik davranışı ile örgütsel adalet algısı arasında anlamlı bir ilişki vardır.

$\mathrm{H}_{2}$ : Paternalist liderlik davranışı ile dağıtımsal adalet algısı arasında anlamlı bir ilişki vardir.

$\mathrm{H}_{3}$ : Paternalist liderlik davranışı ile işlemsel adalet algısı arasında anlamlı bir ilişki vardır.

$\mathrm{H}_{4}$ : Paternalist liderlik davranışı ile etkileşimsel adalet algısı arasında anlamlı bir ilişki vardir.

\subsection{Evren Örneklem}

Araştırmanın evrenini Türkiye'deki büyükşehirler haricindeki illerde bulunan kamu hastaneleri ve özel hastaneler oluşturmaktadır. Bu hastaneleri temsilen, araştırmacının kolay ulaşabileceği Kastamonu, Çankırı ve Karabük illerindeki dört hastane örneklem olarak seçilmiş̧ir.

Örneklem hesaplamada, evrendeki kişi sayısı 545 455, \%95 güven düzeyinde, $\% 5$ hata payı ile örneklem büyüklüğü 384 olarak hesaplanmıştır. Örnekleme seçimi olarak gelişigüzel 
örnekleme yapılmıştır. Toplam 706 sağlık personeli araştırmaya katılmayı kabul etmiştir. Eksik veya yanlış kodlama yapılan 23 ölçek araştırmaya dahil edilmemiştir. Dağıtılan ölçekleri eksiksiz ve doğru şekilde dolduran 683 kişinin ölçekleri değerlendirilmeye alınmıştır.

Katılımcıların \%67,9'unu kadınlar, \%32,1'ini ise erkekler oluşturmaktadır. Yaş gruplarına göre dağılım ise şu şekildedir, \%24'ü $16-25$ yaş, \%36,5'i 26-35 yaş, \%35,9'u 36-50 yaş aralığındadır ve \%3,6'sı ise 51 yaş ve üzerindedir. Araştırmaya katılanların \%32,7'si lise, $\% 57,7$ 'si üniversite, \%9,6's1 ise lisansüstü eğitim mezunudur. Katılımcıların, \%7,9'u hekim, $\% 47$ 'si hemşire, \%5,8'i sağlık memuru, \%6,9'u ebe, \%7,6'sı tıbbi sekreter, \%4,4'ü laboratuvar teknikeri, \%9,4'ü acil tıp teknikeri, \%5'i radyoloji teknikeri, \%2,8'i anestezi teknikeri, \%3,2'si ise diğer sağlık personellerinden oluşmaktadır.

\subsection{Veri Toplama Araçları}

Bu çalışmada, sağlık çalışanlarının sosyodemografik özelliklerini belirlemek için "Kişisel Bilgi Formu", paternalist liderlik algısını ölçmek için "Paternalist Liderlik Ölçeğì", örgütsel adalet algısını ölçmek için "Örgütsel Adalet Ölçeği” kullanılmıştır.

$\mathrm{Bu}$ araştırmada paternalist liderlik davranışlarını ölçmek için Pellegrini ve Scandura (2006) tarafindan geliştirilen ve 13 maddeden oluşan Paternalist Liderlik Ölçeği kullanılmıştır. Beşli likert tipi olan ölçekte " $1=$ kesinlikle katılmıyorum", " $2=$ katılmıyorum", " $3=$ kısmen kat1lıyorum", 4=kat1lıyorum", "5=kesinlikle katılıyorum", şeklinde ifadeler yer almaktadır.

Örgütsel Adalet algısını ölçmek için Niehoff ve Moorman (1993) tarafından geliştirilen ve Yıldırım (2007) tarafından Türkçeye uyarlanan Örgütsel Adalet Ölçeği kullanılmıştır. Ölçek örgütsel adaletin boyutları ölçmek için dağıtımsal adalet ile ilgili ifadeler $(1,2,3,4,5)$, işlemsel adalet ilgili ifadeler $(6,7,8,9,10,11)$ ve etkileşimsel adalet ile ilgili ifadeler $(12,13,14,15,16$, $17,18,19,20)$ yer almaktadır. Ölçek 1'den (kesinlikle yanlış), 5'e kadar (kesinlikle doğru) değişen puanlamaya sahip beşli likert tipi bir ölçektir.

\subsection{Araştırmada Kullanılan Ölçeklerin Güvenilirliği}

Araştırmada kullanılan ölçeklerin güvenilirliği Cronbach's Alpha güvenilirlik katsayısı kullanılarak güvenilirlik analizi yapılmıştır ve sonuçlar Tablo 1'de gösterilmiştir.

Örgütsel adalet ölçeğinin güvenilirlik analizi sonucuna göre; dağıtımsal adalet boyutu Cronbach's Alpha değeri 0,829, işlemsel adalet boyutu Cronbach's Alpha değeri 0,876, etkileşimsel adalet boyutu Cronbach's Alpha 0,921 ve genel örgütsel adalet ölçeği Cronbach's Alpha değeri 0,939 olarak tespit edilmiştir ve ölçeğin yüksek düzeyde güvenilir olduğu saptanmıştır. Ölçeğin orijinal formu (Niehoff ve Moorman, 1993) için Cronbach Alpha güvenirlik katsayılarının; dağıtımsal adalet 0,74 , işlemsel adalet 0,85 ve etkileşimsel adalet 0,92 olduğu bildirilmektedir. Ölçeğin Türkçe'ye çevrilmiş formunda (Yıldırım, 2007), güvenirlik katsayılarının; dağıtımsal adalet 0,81 , işlemsel adalet 0,89 ve etkileşimsel adalet 0,95 olduğu belirlenmiştir.

Paternalist liderlik ölçeğinin güvenilirlik analizi sonucunda ise Cronbach's Alpha değeri 0,890 olarak bulunmuştur ve yüksek düzeyde güvenilir olduğu tespit edilmiştir. Pellegrini ve Scandura (2006), ise ölçeğin Cronbach's Alpha değerini 0,86 olarak tespit edilmiştir.

Tablo 1. Araştırmada kullanılan ölçeklerin güvenirlik analizi sonuçları

\begin{tabular}{llc}
\hline Ölçek & Alt Boyutlar & Cronbach Alpha Değeri \\
Örgütsel Adalet Algısı Ölçeği & Prosedürel adalet & 0.829 \\
& İşlemsel adalet & 0.876 \\
& Etkileşimsel adalet & 0.921 \\
& Genel örgütsel adalet & 0,939 \\
Paternalist Liderlik Ölçeği & & 0.890 \\
\hline
\end{tabular}




\subsection{Kullanılan İstatistiksel Yöntemler}

Ölçek uygulaması sonucunda elde edilen verilerin analizinde SPSS 16 (Statistical Package for Social Sciences) programı kullanılarak, tanımlayıc1 istatistiksel metotlar (say1, yüzde, ortalama, standart sapma) kullanılmıştır. Ölçümsel değişkenler arasındaki ilişkinin incelenmesinde ise Korelasyon Analizi ve Basit Doğrusal Regresyon Analizi yapılmıştır.

\section{Bulgular}

Bu bölümde, araştırmaya konu olan hipotezler test edilmektedir. Hipotezlerde yer alan değişkenler arasındaki ilişkiyi ortaya koymak için Pearson Korelasyon Analizi uygulanmıştır. Paternalist liderlik ile örgütsel adalet arasındaki ilişkiyi ortaya koymak için yapılan korelasyon analizi bulguları Tablo 2'de verilmiştir.

Yapılan korelasyon analizi sonucuna göre paternalist liderlik ile örgütsel adalet algısı arasında pozitif yönlü $(\mathrm{r}=0,659)$ ve yüksek düzeyde anlamlı ilişki olduğu tespit edilmiştir $(\mathrm{p}<0,01)$. Paternalist liderlik ile dağıtımsal adalet arasında orta düzeyde pozitif yönlü $(\mathrm{r}=0,508)$ anlamlı bir ilişki olduğu saptanmıştır $(\mathrm{p}<0,01)$. Paternalist liderlik ile işlemsel adalet arasındaki korelasyon analizi sonucuna göre, paternalist liderlik ile işlemsel adalet arasında orta düzeyde, pozitif yönlü $(r=0,562)$ anlamlı bir ilişki olduğu tespit edilmiştir $(\mathrm{p}<0,01)$. Paternalist liderlik ile etkileşimsel adalet algısı arasındaki ilişkiyi ortaya koymak için yapılan korelasyon analizi sonucunda ise paternalist liderlik ile etkileşimsel adalet algisı arasında yüksek düzeyde, pozitif yönlü $(\mathrm{r}=0,624)$ anlamlı bir ilişki olduğu saptanmıştır $(\mathrm{p}<0,01)$.

Tablo 2. Paternalist liderlik ile örgütsel adalet arasındaki korelasyon analizi bulguları

\begin{tabular}{llccccccc}
\hline & Değişkenler & Ort. & S.S. & 1 & 2 & 3 & 4 & 5 \\
\hline 1. & Paternalist liderlik & 3,18 & 0,83 & 1 & $0,508^{* *}$ & $0,562^{* *}$ & $0,624^{* *}$ & $0,659^{* *}$ \\
2. & Dağıtımsal Adalet & 2,98 & 0,95 & & 1 & $0,523^{* *}$ & $0,634^{* *}$ & $0,793^{* *}$ \\
3. & İşlemsel Adalet & 2,96 & 0,95 & & & 1 & $0,699^{* *}$ & $0,853^{* *}$ \\
4. & Etkileşimsel Adalet & 3,16 & 0,93 & & & & 1 & $0,934^{* *}$ \\
5. & Örgütsel Adalet & 3,05 & 0,82 & & & & & 1 \\
\hline
\end{tabular}

$* *: p<0.01$

Paternalist liderliğin, örgütsel adalet üzerine etkisini test etmek için Basit Doğrusal Regresyon Analizi yapılmıştır ve bulgular Tablo 3'te gösterilmiştir. Basit Doğrusal Regresyon Analizi yapılırken, paternalist liderlik bağımsız değişken olarak belirlenmiştir, örgütsel adalet, dağıtımsal adalet, işlemsel adalet ve etkileşimsel adalet ise bağımlı değişkenler olarak belirlenmiştir.

Paternalist liderliğin, örgütsel adalet üzerinde pozitif yönde ve anlamlı bir etkisi olduğu tespit edilmiştir $(\beta=0,659, \mathrm{t}=22,865, \mathrm{p}<0,01)$. Örgütsel adalet üzerinde meydana gelen değişikliğin \%43,4'ün paternalist liderlik tarafından açıklanmaktadır $\left(\mathrm{R}^{2}=0,434\right)$.

Paternalist liderliğin, dağıtımsal adalet üzerinde, pozitif yönde ve anlamlı bir etkisi olduğu saptanmıştır $(\beta=0,508, \mathfrak{t}=15,397, \mathrm{p}<0,01)$. Dağıtımsal adalet üzerinde meydana gelen değişikliğin \%25,8'in paternalist liderlik tarafından açıklanmaktadır $\left(\mathrm{R}^{2}=0,258\right)$.

Paternalist liderliğin, işlemsel adalet üzerine, pozitif yönde ve anlamlı bir etkisi olduğu tespit edilmiştir $(\beta=0,562, \mathfrak{t}=17,712, \mathrm{p}<0,01)$. İşlemsel adalet üzerinde meydana gelen değişikliğin \%31,5'ün paternalist liderlik tarafından açıklanmaktadır $\left(\mathrm{R}^{2}=0,315\right)$.

Paternalist liderliğin, etkileşimsel adalet üzerine, pozitif yönde ve anlamlı bir etkisi olduğu tespit edilmiştir $(\beta=0,624, t=20,842, p<0,01)$. Etkileşimsel adalet üzerinde meydana gelen değişikliğin \%38,9'u paternalist liderlik tarafından açıklanmaktadır $\left(\mathrm{R}^{2}=0,389\right)$. 
Tablo 3. Paternalist liderliğin, örgütsel adalet üzerindeki etkisine yönelik yapılan basit doğrusal regresyon analizi bulguları

\section{Bağımsız Değişken: Paternalist Liderlik}

\begin{tabular}{lccccccc}
\cline { 2 - 7 } $\begin{array}{l}\text { Bağımlı } \\
\text { Değişkenler }\end{array}$ & $\mathrm{B}$ & Beta $(\beta)$ & $\mathrm{t}$ & $\mathrm{R}^{2}$ & $\begin{array}{c}\text { Düzeltilmiş } \\
\mathrm{R}^{2}\end{array}$ & $\mathrm{~F}$ & $\mathrm{p}$ \\
\hline Örgütsel Adalet & 0,654 & 0,659 & 22,865 & 0,434 & 433 & 522 & 0,000 \\
Dağıtımsal Adalet & 0,583 & 0,508 & 15,397 & 0,258 & 0,257 & 237,073 & 0,000 \\
İşlemsel Adalet & 0,644 & 0,562 & 17,712 & 0,315 & 0,314 & 313,723 & 0,000 \\
Etkileșimsel Adalet & 0,701 & 0,624 & 20,842 & 0,389 & 0,89 & 434,373 & 0,000 \\
\hline
\end{tabular}

\section{Tartışma}

$\mathrm{Bu}$ araştırma, sağlık yöneticilerinin göstermiş oldukları paternalist liderlik davranışının, çalışanların örgütsel adalet algısı üzerine etkisi olup olmadığını ortaya koymak amacı ile yapılmıştır.

$\mathrm{H}_{1}$ : Paternalist liderlik davranışları ile örgütsel adalet algısı arasında anlamlı bir ilişki vardir.

Yapılan korelasyon analizi sonucuna göre paternalist liderlik ile örgütsel adalet algıs1 arasında pozitif yönlü $(\mathrm{r}=0,659)$ ve yüksek düzeyde, istatistiksel açıdan anlamlı ilişki olduğu tespit edilmiştir $(\mathrm{p}<0,01)$. Basit doğrusal regresyon analizi sonucuna göre, paternalist liderliğin, örgütsel adalet algısı üzerine pozitif yönlü ve anlamlı bir etkisi olduğu belirlenmiştir $(\beta=0,438$, $\mathrm{t}=12,700, \mathrm{p}<0,01)$. Bu sonuçlara göre, $\mathrm{H}_{1}$ hipotezi kabul edilmiştir. vardir.

$\mathrm{H}_{2}$ : Paternalist liderlik davranışları ile dağıtımsal adalet algısı arasında anlamlı bir ilişki

Paternalist liderlik ile dağıtımsal adalet arasındaki korelasyon analizi sonucuna göre paternalist liderlik ile dağıtımsal adalet arasında orta düzeyde, pozitif yönlü $(\mathrm{r}=0,508)$, istatistiksel açıdan anlamlı bir ilişki olduğu tespit edilmiştir $(p<0,01)$. Basit doğrusal regresyon analizi sonucuna göre paternalist liderliğin, dağıtımsal adalet üzerine, yüksek düzeyde ve pozitif yönde anlamlı bir etkisi olduğu tespit edilmiştir $(\beta=0,508, t=15,397, p<0,01)$. Bu sonuçlara göre, $\mathrm{H}_{2}$ hipotezi kabul edilmiştir. vardir.

$\mathrm{H}_{3}$ : Paternalist liderlik davranışları ile işlemsel adalet algısı arasında anlamlı bir ilişki

Paternalist liderlik ile prosedürel adalet arasında orta düzeyde, pozitif yönlü $(r=0,562)$ istatistiksel açıdan anlamlı bir ilişki olduğu saptanmıştır $(\mathrm{p}<0,01)$. Basit doğrusal regresyon analizi sonucuna göre paternalist liderliğin, dağıtımsal adalet üzerinde, pozitif yönde ve anlamlı bir etkisi olduğu saptanmıştır $(\beta=0,562, \mathrm{t}=17,712, \mathrm{p}<0,01)$. Elde edilen sonuçlara göre, $\mathrm{H}_{3}$ hipotezi kabul edilmiştir.

$\mathrm{H}_{4}$ : Paternalist liderlik davranışları ile Etkileşimsel Adalet algısı arasında anlamlı bir ilişki vardir.

Paternalist liderlik ile etkileşimsel adalet algısı arasındaki ilişkiyi ortaya koymak için yapılan korelasyon analizi sonucunda ise paternalist liderlik ile etkileşimsel adalet algısı arasında yüksek düzeyde, pozitif yönlü $(\mathrm{r}=0,624)$, istatistiksel açıdan anlamlı bir ilişki olduğu saptanmıştır $(\mathrm{p}<0,01)$. Basit doğrusal regresyon analizi sonucuna göre, paternalist liderliğin, etkileşimsel adalet üzerine, pozitif yönde ve anlamlı bir etkisi olduğu tespit edilmiştir $(\beta=0,624, t=20,842$, $\mathrm{p}<0,01)$. Elde edilen sonuçlara göre, $\mathrm{H}_{4}$ hipotezi kabul edilmiştir.

Yeşiltaş'ın (2013), paternalist liderliğin örgütsel vatandaşlık davranışlarına etkisinde dağıtım adaletinin aracılık rolünü belirlemek amacı ile İstanbul'da faaliyet gösteren otel çalışanları üzerinde yaptığı araştırmada paternalist liderliğin (Yardımsever ve ahlaki liderlik 
boyutları hariç) dağıtım adaleti ile arasında pozitif yönlü bir ilişki olduğu sonucuna varmıştır (Yeşiltaş, 2013). Kayseri ilinde tekstil sektöründe çalışanlar üzerinde Köksal (2011) tarafından yapılan araştırmada, paternalist liderlik algısı ile işlemsel adalet ve etkileşimsel adalet algısı arasında pozitif ilişki olduğu belirlenmiştir. Sağlık çalışanları üzerinde, bu konuda daha önce yapılmış bir çalışmaya rastlanmamıştır. Ancak iki farklı sektörde yapılan araştırmaların sonuçları ile bizim çalışmamızın sonuçlarının örtüştüğ̈ görülmektedir.

\section{Sonuç ve Öneriler}

$\mathrm{Bu}$ araştırmada Paternalist Liderlik davranışı arttıkça, sağlık çalışanlarının örgütsel adalet algısının da arttığı saptanmıştır. Sağlık yöneticileri Paternalist Liderlik davranışı gösterdiği oranda çalışanlarında örgütsel adalet algısının artması beklenmektedir. Tüm bu sonuçlara göre paternalist liderliğin, sağlık çalışanları üzerinde etkin bir liderlik modeli olduğu söylenebilir.

Sağlık yöneticilerinin daha fazla paternalist liderlik davranışı göstermesi için paternalist liderlik konusunda yöneticilere ve yönetici adaylarına eğitim verilmesi faydalı olabilir.

Literatürde paternalist liderlik ile örgütsel adalet algısı üzerindeki etkisini araştırmaya yönelik yapılan çalışmaların kısıtlı olduğu görülmektedir. $\mathrm{Bu}$ konuda yeni araştırmalar yapılmasının faydalı olacağı düşünülmektedir.

Çalışanlar kendilerine verilen ücretimin adil olmadığını düşünmektedirler, bunun nedeni döner sermaye adı altında dağıtılan ek ödemelerin dağıtımı ile ilgili olabilir. Çünkü ek ödemeler, hekimlere bireysel performanslarına (yapılan işlem sayısına) göre ödenmekte iken diğer sağlık personellerine çalıştıkları birimlerin özelliğine göre genel ortalamadan ödenmektedir. Performansa dayalı ödemeler yapılan işlem sayısından (niceliğe) ziyade yapılan işin kalitesine (niteliğine) göre yapılması ve bireysel performansa göre olması, bu sorunun çözümünde etkili olabilir.

Çalışanların, yöneticilerin iş ile ilgili kararların alırken kendilerinin görüşlerinin alınmadığı konusundaki algılarının düşük olduğu saptanmıştır. Yöneticiler, çalışanları ilgilendiren konularda kararlar alırken çalışanlarında görüşlerini alması, yönetim sürecine onları da dahil etmesi hem çalışanların örgütsel adalet algılarını artıracaktır hem de motivasyonları üzerinde olumlu etkileri olacaktır.

\section{Kaynakça}

Acar, P. (2013). Örgütsel Öğrenme, Vatandaşlık ve Adalet, İçinde: Örgütsel Davranış (Ed: Ç.A. Kırel ve O. Ağlargöz), Eskişehir: Anadolu Üniversitesi Yayınları.

Alqurashi, S.M. (2015). The Relationship Between Organizational Justice And Psychological Empowerment of Saudi Public Employees, International Journal of Business \& Public Administration, 12(1): 41-67.

Anwar, H. (2013). Impact of Paternalistic Leadership on Employees Outcome A Study on The Banking Sector of Pakistan, IOSR Journal Of Business And Management, 7(6): 109-115.

Aycan, Z., Kanungo, R., Mendonca, M., Yu, K., Deller, J., Stahl, G. \& Kurshid, A. (2000). Impact of Culture on Human Resource Management Practices: A 10-Country Comparison, Applied Psychology, 49(1): 192-221.

Aycan, Z. (2006). Paternalism: Towards Conceptual Refinement and Operationalization. In: Scientific Advances in Indigenous Psychologies: Empirical, Philosophical, and Cultural Contributions (Ed: Yang, K.S., Hwang, K.K., Kim, U.), London: Cambridge University Press.

Bağcı, Z. (2013). Çalışanların Örgütsel Adalet Algılarının Örgütsel Bağlılıkları Üzerindeki Etkisi: Tekstil Sektöründe Bir İnceleme, Uluslararası Yönetim Íktisat ve İşletme Dergisi, 9(19): 163 184. 
Cheng, B. S., Boer, D., Chou, L. F., Huang, M. P., Yoneyama, S., Shim, D., Sun, J. M., Ling, T. T. and Tsai, C. Y. (2014). Paternalistic Leadership in Four East Asian Societies Generalizability and Cultural Differences of The Triad Model, Journal of Cross-Cultural Psychology, 45(1): 82-90.

Cheng, M. Y. and Wang, L. (2015). The Mediating Effect of Ethical Climate on The Relationship Between Paternalistic Leadership and Team İdentification: A Team-Level Analysis in The Chinese Context, Journal Of Business Ethics, 129(3): 639-654.

Colquitt, J. A., Conlon, D. E., Wesson, M. J., Porter, C. O. \& Ng, K. Y. (2001). Justice at The Millennium: A Meta-Analytic Review of 25 Years of Organizational Justice Research, Journal Of Applied Psychology, 86(3): 425-445.

Colquitt, J.A. (2001). On The Dimensionality of Organizational Justice: A Construct Validation Of A Measure, Journal of Applied Psychology, 86(3): 386-400.

Cropanzano, R., Bowen, D.E. \& Gilliland, S.W. (2007). The Management of Organizational Justice, The Academy of Management Perspectives, 21(4): 34-48.

Cüce, H., Güney, S. ve Tayfur, Ö. (2013). Örgütsel Adalet Algılarının Örgütsel Özdeşleşme Üzerindeki Etkisini Belirlemeye Yönelik Bir Araştırma, Hacettepe Üniversitesi İktisadi ve İdari Bilimler Fakültesi Dergisi, 31(1): 1-30.

DeConinck, J. B. (2010). The Effect of Organizational Justice, Perceived Organizational Support, And Perceived Supervisor Support on Marketing Employees Level of Trust, Journal of Business Research, 63(12): 1349-1355.

Eren, E. (2015). Örgütsel Davranış ve Yönetim Psikolojisi, 15. Bask1, İstanbul: Beta Basım.

Fortin, M. (2008). Perspectives on Organizational Justice: Concept Clarification, Social Context İntegration, Time and Links With Morality, International Journal of Management Reviews, 10(2): 93-126.

Gelfand, M. J., Erez, M. \& Aycan, Z. (2007). Cross-Cultural Organizational Behavior, Annual Review of Psychology, 58: 479-514.

Köksal, O. (2011). Bir Kültürel Liderlik Paradoksu: Paternalizm, Mustafa Kemal Üniversitesi Sosyal Bilimler Enstitüsü Dergisi, 8(15): 101-122.

Leventhal, G. S. (1980). What Should be Done With Equity Theory? New Approaches to The Study of Fairness in Social Relationships, In: Social Exchange Theory(Eds: K.J. Gergen, M.S. Greenberg, RH. Willis), New York: Plenum Press.

Lu, F. J. H. and Hsu, Y. (2015). The Interaction Between Paternalistic Leadership and Achievement Goals in Predicting Athletes Sportspersonship, Kinesiology: International Journal of Fundamental and Applied Kinesiology, 47(1): 115-122.

MacLeod, L. (2015). The Physician Leader's Role in Promoting Organizational Justice, Physician Leadership Journal, 2(5): 38-49.

Malik, M. E. and Naeem, B. (2011). Impact of Perceived Organizational Justice on Organizational Commitment of Faculty: Empirical Evidence From Pakistan, Interdisciplinary Journal of Research in Business, 1(9): 92-98.

Miles, J. A. (2012). Management And Organization Theory, A Jossey-Bass Reader: San Francisco: John Wiley \& Sons.

Mustafa, G. and Lines, R. (2012). Paternalism As a Predictor of Leadership Behaviors: A BiLevel Analysis, Eurasian Business Review, 2(1): 63-92. 
Nakra, R. (2014). Understanding The İmpact of Organizational Justice on Organizational Commitment and Projected Job Stay Among Employees of The Business Process Outsourcing Sector in India, Vision The Journal of Business Perspective, 18(3): 185-194.

Önen, S. M. ve Kanayran, H. G. (2015). Liderlik ve Motivasyon: Kuramsal Bir Değerlendirme, Birey ve Toplum Sosyal Bilimler Dergisi, 5(2): 43-64.

Pellegrini, E. K. and Scandura, T. A. (2006). Leader-Member Exchange (LMX), Paternalism and Delegation in The Turkish Business Culture: An Empirical Investigation, Journal of International Business Studies, 37(2): 264-279.

Pellegrini, E. K. and Scandura, T. A. (2008). Paternalistic Leadership: A Review and Agenda for Future Research, Journal of Management, 34(3): 566-593.

Salminen-Karlsson, M. (2015). Expatriate Paternalistic Leadership and Gender Relations in Small European Software Firms in India, Culture and Organization, 21(5): 409-426.

Sia, L. A. \& Tan, T. A. G. (2016). The İnfluence of Organizational Justice on Job Satisfaction in A Hotel Setting, DLSU Business \& Economics Review, 26(1): 17-29.

Sur, H. (2013). Çalışanların motivasyonu ve İş Doyumu, İçinde: Hastane Yönetimi, (Ed: H. Sur ve T. Palteki), 10 Bask1, İstanbul: Nobel Tip Kitabevi.

Tahseen, N. and Akhtar, M. S. (2016). Impact of Organizational Justice on Citizenship Behavior: Mediating Role of Faculty Trust, Pakistan Journal of Commerce and Social Sciences, 10(1): 104-121.

Tanrıverdi, H. ve Paşağlu, S. (2014). Dönüşümcü Liderlik, Örgütsel Adalet ve İş Tatmini Arasındaki İlişkileri Belirlemeye Yönelik Okul Öncesi Öğretmenleri Üzerinde Bir Araştırma, Elektronik Sosyal Bilimler Dergisi, 13(50): 274-293.

Türesin, H. (2012). Örgüt Çalışanlarının Paternalistik Liderlik Algıları, Öğrenilmiş Güçlülük Düzeyleri, İs Tatmin Düzeyleri ve İșten Ayrlma Niyetleri Arasindaki İlişkilerin İncelenmesi, Celal Bayar Üniversitesi Sosyal Bilimler Enstitüsü, Yüksek Lisans Tezi, Manisa.

Ünler, E. (2015). Örgütsel Adalet, İçinde: Örgütsel Adaletin Peşinde (Ed: E. Ünler ve H. Gürel), İstanbul: Beta Yayınları.

Yaman, T. (2011). Yöneticilerin Paternalist (Babacan) Lider Davranışlarının Çalışanların Örgütsel Özdeşleşmelerine, İş Performanslarına ve İşten Ayrılma Niyetlerine Etkisi: Özel Sektörde Uygulama, Kara Harp Okulu, Savunma Bilimleri Enstitüsü, Yüksek Lisans Tezi, Ankara.

Yeşiltaş, M. (2013). Paternalist Liderliğin Örgütsel Vatandaşlık Davranışları Üzerindeki Etkisinde Dağıtım Adaletinin Aracılık Rolü, İşletme Araştırmaları Dergisi, 5(4): 50-70.

Yıldırım, F. (2007). İş Doyumu İle Örgütsel Adalet İlişkisi, Ankara Üniversitesi SBF Dergisi, 62(01): 253-278. 